\title{
Crops and Cropping Sequences in Chittagong Hill Tracts
}

\author{
M K Quais ${ }^{1 *}$, M Harunur Rashid ${ }^{1}$, S M Shahidullah ${ }^{1}$ and M Nasim ${ }^{1}$
}

\begin{abstract}
This study was conducted in all 25 upazilas of Chittagong Hill Tracts during 2016 using a pre-designed and pre-tested semi-structured questionnaire for documenting the existing cropping pattern, crop diversity and cropping intensity. Boro-Fallow-T. Aman was the most dominant cropping pattern in Chittagong Hill Tracts (15.06\%) existed in all upazilas except Ruma of Bandarban. Single T. Aman cropping pattern ranked the second position (13.67\%) distributed in 21 upazilas. Shifting or zhum cultivation was the third cropping pattern in the region (9.24\%) distributed to 20 upazilas. Only Rabi vegetables was recorded as the fourth cropping pattern $(4.90 \%)$ covered 17 upazilas. VegetablesFallow-T. Aman cropping pattern ranked fifth (4.23\%) in the region and was reported in 22 upazilas. About $30 \%$ area was covered by the annual crops mainly with fruits like banana, pineapple and papaya and, spices like ginger and turmeric. The highest number of cropping patterns was recorded in Lama (30) of Bandarban followed by Dighinala (28) of Khagrachhari. The lowest was reported in Ruma (8) of Bandarban. The overall crop diversity index (CDI) for the region was 0.96. The highest CDI was in Rowangchhari (0.99) of Bandarban followed by Lama (0.96) of Bandarban and the lowest in Belaichhari (0.82) of Rangamati. The single, double and triple cropped area in the region was $33.3 \%, 32.1 \%$ and $3.1 \%$ of the net cropped area. The average cropping intensity (CI) of the Chittagong Hill Tracts was $139 \%$, the lowest in Ruma (100\%) of Bandarban and the highest in Manikchhari and Panchhari (164\%) of Khagrachhari.
\end{abstract}

Key words: Cropping patterns, land use, cropping intensity, diversity index and hill tract

\section{INTRODUCTION}

Number of crops grown under different cropping patterns varies from region to region. Cropping pattern influences the consumption pattern as well as health and nutritional status of the people (Barua et al., 2015). A cropping pattern is defined as yearly sequences of crop production in a piece of land are grown in the course of a year (Alam, 1994). A large number of factors like climate, soil type, rainfall, insect and disease pressure, agricultural technology; availability of irrigation facilities and other inputs, marketing and transport facilities, subsistence pressure and the growth of agroindustries influence on the cropping pattern and the changes therein (Neema, 1998; Gadge, 2003; Rashid et al., 2005).
The Chittagong Hill Tracts (CHT) presents unique biophysical characteristics, ethnic diversity and farming practices following certain cropping pattern that has taken care of the lives support of the hill people including dwelling, food, clothing, health care, festivities and other activities (Khisa, 1998). The CHT districts of the country have generally been identified as a disadvantaged region in terms of poverty, food insecurity, environmental vulnerability and limited livelihood opportunities. The stress environment of the hilly areas of the country received very little attention in the past. The increased pressure of growing population demand more food that brings attention to explore the possibilities of increasing the potential of the hilly lands for increased production of crops. Moreover, cultivable land area is decreasing day by day

${ }^{1}$ Rice Farming Systems Division, BRRI, Gazipur; *Corresponding author's E-mail: quaisbau@yahoo.com 
in the country. In this context, there is no other alternative but to address less fabourable and unfavourable environments for food security and to adapt to the climatic variability. The overall strategy for seventh five year plan of Bangladesh is to accelerate the process of transformation from existing semi-subsistence farming to commercialization of agriculture. The strategy requires achieving productivity gains, diversification, value addition and agro-processing commensurate with national environment protection and climate change adaptation strategies. (GED, 2015).

The increased total system productivity of an environment needs diversity in enterprises for better use of limited resources. Detailed information on land use and cropping systems is a pre-requisite for a fruitful development programmes on crop intensification and diversification for food and nutritional security. The Department of Agricultural Extension maintains a statistics on individual crop at upazila level. However, there is lacking of authenticated information on cropping pattern and cropping intensity at upazila and regional level. The present scenario of cropping patterns of a particular area may guide policy makers, researchers and extension personnelfor taking initiative to fulfill the implementation of priority plan of Sustainable Development Goal and Seventh Five year Plan for ending poverty and achieving food security. The present study was designed with the following specific objectives to:

- Understand the existing cropping patterns scenario in the CHT

- Visualize the existing land use pattern at upazila and regional level

- Determine the crop diversity and cropping intensity at local and regional level.

\section{METHODOLOGY}

Twenty-five upazilas of Bandarban, Rangamati and Khagrachhari districts under Chittagong Hill Tracts agricultural region were the locale of this study. Data were collected using double stage procedure. At initial stage, data were collected through pre-tested, semi-structured questionnaire from 25 preassigned Sub-Assistant Agriculture Officers (SAAO) of each upazila during March 2016 at upazila level. The SAAOs were purposively preselected by Agriculture Extension Officers (AEO), Additional Agriculture Officer (AAO) and Upazila Agriculture Officer (UAO) or altogether. Prior to data collection, the pretested questionnaire was explained along with proper guidelines to the AEOs or UAOs or both and handed over to them at each Deputy Director's office of Department of Agricultural Extension (DAE) during monthly meeting for the sake of accurate data collection. The filled questionnaires were collected by the scientists of RFS Division, checked and analyzed to find the inconsistencies of the supplied data before validation workshop. All the inconsistencies among the information were documented. The collected data along with documented inconsistencies were discussed in district level workshop to for necessary correction and validation. Second stage of data collection was daylong data validation workshop at district level during 16 to 18 May 2016. Four fieldworkers i.e. one SAPPO and three SAAOs experienced and engaged in crop-based data documentation, all officers from all upazilas viz UAOs, AEOs, AAEOs, DD (DAE), DD (Horticulture), DD of Seed Certification Agency, DTO and ADDs, one representative from Agricultural Training Institute (ATI) and scientists of BRRI regional station, Satkhira, Bhanga and Rajshahi participated in the data validation workshop. The number participants of validation workshop ranged from 48 to 63 in each district. All the participants were divided into three to four groups for data validation. Each group was facilitated by two RFSD scientists to finalize and validate the data and authenticated data were captured. Crop diversity index was calculated by using the following equation described by Kshirsagar et al. (1997).

$$
C D I_{i}=1-\sum_{j=o}^{n}\left(\frac{a_{i j}}{A_{i}}\right)^{2}
$$

Where, $\mathrm{CDI}_{\mathrm{i}}=$ Crop Diversity Index 
$a_{i j}=$ Area planted to the $j^{\text {th }}$ crop in the $i^{\text {th }}$ location

$A_{i}=$ Total area planted under all crops

The index is zero for a land area growing only one crop approaches unity as the level of diversity increase. Data were compiled and processed using Micro Soft Excel programme. Descriptive statistics were used to facilitate the presentation of the findings.

\section{RESULTS AND DISCUSSION}

\section{Land use}

Crops occupied the particular land for round the year were considered under annual crops. The major annual crops reported in Chittagong hill tracts were banana, turmeric, ginger, pineapple, papaya and sugarcane (Table 1). The area under annual crops in different upazilas ranged from 480 to 4,550 ha. The annual crops area accounted about $30 \%$ of the net cropped area (NCA) in the region. Among the annual crops, banana was widely distributed with higher area coverage. Ginger was distributed in 23 upazilas ranged 120 to 520 ha. Turmeric was reported in all upazilas except Naikhongchhari with a range of 130 to 980 ha. Pineapple was found in 19 upazilas with a major contribution from Ruma, Nannerchar, and Rowangchhari. Papaya was reported in 17 upazilas with an area coverage of five to 300 ha. Sugarcane was also reported in all upazilas except Barkal with a narrow area coverage (5-85 ha).

The single cropped area (SCA) had the major share in NCA in Ruma, Thanchi, Matiranga, Baghaichhari, Barkal, Belaichhari, Kawkhali, Langadu and Rangamati sadar followed by corresponding double cropped area (DCA). The rest of the upazilas were dominated by DCA (Table 2). The proportion of triple cropped

Table 1. Upazila wise area coverage under annual crops in Chittagong Hill Tracts, 2014-15.

\begin{tabular}{|c|c|c|c|c|c|c|c|c|c|}
\hline & Upazila & $\begin{array}{c}\text { Banana } \\
\text { (ha) }\end{array}$ & $\begin{array}{l}\text { Ginger } \\
\text { (ha) }\end{array}$ & $\begin{array}{c}\text { Papaya } \\
\text { (ha) }\end{array}$ & $\begin{array}{c}\text { Pineapple } \\
\text { (ha) }\end{array}$ & $\begin{array}{c}\text { Sugar- } \\
\text { cane (ha) }\end{array}$ & $\begin{array}{c}\text { Turmeric } \\
\text { (ha) }\end{array}$ & $\begin{array}{c}\text { Total } \\
\text { (ha) }\end{array}$ & $\begin{array}{l}\% \text { NCA in } \\
\text { the region }\end{array}$ \\
\hline 01 & Alikadam & 1400 & 0 & 300 & 200 & 30 & 0 & 1930 & 1.50 \\
\hline 02 & Bandarb.sadar & 560 & 190 & 30 & 160 & 30 & 130 & 1100 & 0.85 \\
\hline 03 & Lama & 800 & 300 & 250 & 60 & 60 & 300 & 1770 & 1.36 \\
\hline 04 & Naikhongch. & 1520 & - & 40 & 10 & 40 & - & 1610 & 1.25 \\
\hline 05 & Rowangchhari & 730 & 120 & - & 555 & 15 & 160 & 1580 & 1.23 \\
\hline 06 & Ruma & 1910 & 350 & 150 & 1800 & 20 & 320 & 4550 & 3.53 \\
\hline 07 & Thanchi & 200 & 450 & 70 & 50 & 20 & 350 & 1140 & 0.89 \\
\hline 08 & Dighinala & 560 & 520 & 65 & 245 & 85 & 695 & 2170 & 1.68 \\
\hline 09 & Khagra. sadar & 80 & 340 & 5 & 10 & 80 & 615 & 1130 & 0.88 \\
\hline 10 & Lakshmichhari & 210 & 370 & - & 20 & 50 & 350 & 1000 & 0.78 \\
\hline 11 & Mohalchhari & 350 & 370 & 50 & 110 & 60 & 530 & 1470 & 1.14 \\
\hline 12 & Manikchhari & - & 210 & - & - & 10 & 260 & 480 & 0.38 \\
\hline 13 & Matiranga & - & 550 & - & - & 30 & 980 & 1560 & 1.21 \\
\hline 14 & Panchhari & 200 & 360 & 30 & - & - & 550 & 1140 & 0.89 \\
\hline 15 & Ramgarh & 400 & 300 & 10 & 30 & 30 & 500 & 1270 & 0.99 \\
\hline 16 & Baghaichhari & - & 180 & - & - & 20 & 300 & 500 & 0.39 \\
\hline 17 & Barkal & 1500 & 170 & - & - & - & 250 & 1920 & 1.49 \\
\hline 18 & Belaichhari & 1200 & 250 & 30 & 10 & 10 & 210 & 1710 & 1.33 \\
\hline 19 & Juraichhari & 230 & 170 & 15 & 10 & 25 & 200 & 650 & 0.50 \\
\hline 20 & Kaptai & 501 & 250 & 30 & 35 & 24 & 350 & 1190 & 0.92 \\
\hline 21 & Kawkhali & 750 & 450 & - & 25 & 25 & 570 & 1820 & 1.41 \\
\hline 22 & Langadu & 1020 & 240 & 40 & 150 & 40 & 130 & 1620 & 1.26 \\
\hline 23 & Nannerchar & 755 & 150 & 160 & 1000 & 15 & 250 & 2330 & 1.81 \\
\hline 24 & Rajasthali & 510 & 200 & 30 & 15 & 15 & 150 & 920 & 0.72 \\
\hline \multirow[t]{2}{*}{25} & Rangam. sadar & 1200 & 360 & - & - & 25 & 135 & 1720 & 1.34 \\
\hline & Total & 16586 & 6850 & 1305 & 4495 & 759 & 8285 & 38280 & 29.73 \\
\hline
\end{tabular}


Table 2. Upazila-wise land use pattern of Chittagong Hill Tracts (area in hectares), 2014-15

\begin{tabular}{|c|c|c|c|c|c|c|c|c|}
\hline & Upazila & $\begin{array}{l}\text { Area of } \\
\text { upazila }\end{array}$ & SCA & DCA & TCA & Other & $\begin{array}{c}\text { Annual } \\
\text { crops }\end{array}$ & NCA (ha) \\
\hline 01 & Alikadam & 57800 & 760 & 2120 & - & 70 & 1930 & 4880 \\
\hline 02 & Bandarban sadar & 50199 & 1740 & 1820 & 80 & 110 & 1100 & 4850 \\
\hline 03 & Lama & 67184 & 2750 & 4660 & 220 & 120 & 1770 & 9520 \\
\hline 04 & Naikhongchhari & 46361 & 2000 & 3840 & 500 & 60 & 1610 & 8010 \\
\hline 05 & Rowangchhari & 44289 & 270 & 750 & 100 & 80 & 1580 & 2780 \\
\hline 06 & Ruma & 49210 & 2280 & 10 & - & 110 & 4550 & 6950 \\
\hline 07 & Thanchi & 102082 & 2310 & 170 & 30 & 90 & 1140 & 3740 \\
\hline 08 & Diginala & 69413 & 2440 & 3190 & 125 & 95 & 2170 & 8020 \\
\hline 09 & Khagrachhari sadar & 11243 & 1065 & 2825 & 150 & 110 & 1130 & 5280 \\
\hline 10 & Lakshmichhari & 22015 & 1030 & 1480 & - & 90 & 1000 & 3600 \\
\hline 11 & Mohalchhari & 25132 & 2780 & 2400 & 600 & 70 & 1470 & 7320 \\
\hline 12 & Manikchhari & 16835 & 1180 & 2170 & 210 & 140 & 480 & 4180 \\
\hline 13 & Matiranga & 49589 & 2550 & 2010 & 480 & 110 & 1560 & 6710 \\
\hline 14 & Panchhari & 33411 & 345 & 1935 & 175 & 95 & 1140 & 3690 \\
\hline 15 & Ramgarh & 24087 & 1750 & 1950 & 430 & 120 & 1270 & 5520 \\
\hline 16 & Baghaichhari & 191403 & 4480 & 3200 & 300 & 120 & 500 & 8600 \\
\hline 17 & Barkal & 76100 & 1500 & 435 & 10 & 105 & 1920 & 3970 \\
\hline 18 & Belaichhari & 74593 & 2410 & 100 & - & 90 & 1710 & 4310 \\
\hline 19 & Juraichhari & 60600 & 980 & 140 & 40 & 40 & 650 & 1850 \\
\hline 20 & Kaptai & 27336 & 800 & 590 & 150 & 60 & 1190 & 2790 \\
\hline 21 & Kawkhali & 33943 & 1405 & 1080 & 0 & 65 & 1820 & 4370 \\
\hline 22 & Langadu & 52059 & 1860 & 890 & 350 & 50 & 1620 & 4770 \\
\hline 23 & Nannerchar & 38793 & 2400 & 2180 & - & 70 & 2330 & 6980 \\
\hline 24 & Rajasthali & 12551 & 640 & 900 & 60 & 100 & 920 & 2620 \\
\hline \multirow[t]{2}{*}{25} & Rangamati sadar & 54640 & 1150 & 495 & - & 55 & 1720 & 3420 \\
\hline & Total & - & 42875 & 41340 & 4010 & 2225 & 38280 & 128730 \\
\hline
\end{tabular}

SCA $=$ Single cropped area, $\mathrm{DCA}=$ Double cropped area, $\mathrm{TCA}=$ Triple cropped area .

Table 3. Cropping patterns with exclusive rice in Chittagong Hill Tracts, 2014-15.

\begin{tabular}{llrrc}
\hline & Cropping pattern & Area (ha) & \% of NCA & Frequency (no. of upazila) \\
\hline 1 & Boro-Fallow-T. Aman & 19400 & 15.07 & 24 \\
2 & Fallow-Fallow-T. Aman & 17610 & 13.68 & 21 \\
3 & Boro-Fallow-Fallow & 4950 & 3.85 & 11 \\
4 & Fallow-Aus-T. Aman & 1320 & 1.03 & 9 \\
5 & Boro-Aus-Fallow & 700 & 0.54 & 3 \\
6 & Boro-Aus-T. Aman & 480 & 0.37 & 5 \\
\hline & Total & 44460 & 34.54 & \\
\hline
\end{tabular}

area (TCA) was lesser than SCA and DCA in all upazilas. The SCA and DCA were more or less similar, 33.29 and $32.10 \%$ of the NCA. The area which could not defined under SCA, DCA, TCA was considered as others.

\section{Cropping patterns of Chittagong Hill Tracts} In total 72 cropping patterns were observed in Chittagong hill tract of which six cropping patterns with exclusive rice crop covers about $35 \%$ of the NCA. There were 20 cropping patterns with exclusive non-rice crop covering $11 \%$ of the NCA. Rest of the NCA i.e. about $54 \%$ area is covered by 46 rice - non rice cropping patterns (Appendix 1).

\section{Rice and non-rice crops at a glance}

Table 3 presents six cropping patterns where rice is the only crop round the year. It comprises $34.54 \%$ of the NCA in the region. Among them single rice, double rice and triple rice areas represent $17.53 \%, 16.64 \%$ and 
Table 4. Cropping patterns of non-rice exclusive in Chittagong Hill Tract, 2014-15.

\begin{tabular}{llcc}
\hline Cropping pattern & Area (ha) & \% of NCA & Frequency (no. of upazila) \\
\hline 01 Vegetab-Fallow-Fallow & 6310 & 4.90 & 17 \\
02 Vegetab-Vegetab-Fallow & 4890 & 3.80 & 14 \\
03 Groundnut-Fallow-Fallow & 480 & 0.37 & 8 \\
04 Tobacco-Fallow-Fallow & 470 & 0.37 & 4 \\
05 Vegetab-Vegetab-Vegetab & 450 & 0.35 & 2 \\
06 S.Potato-Fallow-Fallow & 410 & 0.32 & 12 \\
07 Chilli-Fallow-Fallow & 170 & 0.13 & 6 \\
08 Chilli-Vegetab-Fallow & 150 & 0.12 & 4 \\
09 Potato-Chilli-Fallow & 130 & 0.10 & 2 \\
10 Felon-Fallow-Fallow & 120 & 0.09 & 2 \\
12 M.Melon-Fallow-Fallow & 120 & 0.09 & 3 \\
13 Mustard-Fallow-Fallow & 110 & 0.09 & 6 \\
14 Maize-Sesame-Fallow & 85 & 0.07 & 6 \\
15 Coriander-Fallow-Fallow & 80 & 0.06 & 2 \\
\hline Total five patterns (in Table 7) & 75 & 0.06 & 6 \\
\hline
\end{tabular}

Table 5. Cropping patterns of pulses and oil-seed crops in Chittagong Hill tract, 2014-15.

\begin{tabular}{rlccc}
\hline Cropping pattern & Area (ha) & \% of NCA & Frequency (no. of upazila) \\
\hline 01 & Groundnut-Fallow-Fallow & 480 & 0.37 & 8 \\
02 & Felon-Fallow-T. Aman & 370 & 0.29 & 9 \\
03 & Mustard-Fallow-T. Aman & 175 & 0.14 & 9 \\
04 & Felon-Fallow-Fallow & 120 & 0.09 & 2 \\
05 & Mustard-Fallow-Fallow & 85 & 0.07 & 6 \\
06 & Felon-Aus-Fallow & 50 & 0.04 & 1 \\
07 & Pea-Fallow-T. Aman & 45 & 0.03 & 6 \\
08 & Lentil-Fallow-T. Aman & 30 & 0.02 & 5 \\
09-17 & Other nine patterns (in Table 7) & 110 & 0.09 & - \\
\hline & Total pulses and oil-seed crops & 1465 & 1.14 & \\
\hline
\end{tabular}

$0.37 \%$, respectively. It reflects the unparallel dominance of rice in the cropping systems in Chittagong Hill Tracts. In case of individual pattern Boro-Fallow-T. Aman has the highest coverage $(15.07 \%)$ and was recorded in 24 upazilas out of 25 . The second dominant pattern single T. Aman area occupied $13.68 \%$ of NCA which was distributed over 21 upazilas. Single Boro covered $3.85 \%$ area with its considerable existence in 11 upazilas.

In the current investigation, 20 cropping patterns were identified that was free from rice. Among these 20 patterns first 15 have been arranged in descending order in Table 4. The rest five patterns with negligible area (Table 7) where they are arranged with other patterns of different categories. Aggregate of the 20 patterns have had $11.01 \%$ of NCA. In critical comparison it is clear that exclusive rice area is three folds of exclusive non-rice area.

\section{Pulses and oil-seed crops}

There are 17 cropping patterns of pulses and oil-seed crops where sole groundnut is the dominating one with 480 ha area (Table 5). Felon-Fallow-T. Aman is the second covering 370 hectares of land. Total area for pulses and oil-seed crops were calculated as 1,465 ha, which is only $1.14 \%$ of NCA.

\section{Vegetables and spices crops}

Thirty-two cropping patterns have been arranged in descending order according to area coverage in Table 6. Potato and other vegetables of Rabi, Kharif-I and Kharif-II; Spices viz chilli, 
Table 6. Cropping patterns of vegetables and spices crops in Chittagong Hill Tract, 2014-15.

\begin{tabular}{|c|c|c|c|c|}
\hline & Cropping pattern & Area (ha) & $\%$ of NCA & Frequency (no. of upazila) \\
\hline 01 & Vegetab-Fallow-Fallow & 6310 & 4.90 & 17 \\
\hline 02 & Vegetab-Fallow-T. Aman & 5450 & 4.23 & 22 \\
\hline 03 & Vegetab-Vegetab-Fallow & 4890 & 3.80 & 14 \\
\hline 04 & Vegetab-Vegetab-T. Aman & 1850 & 1.44 & 7 \\
\hline 05 & Vegetab-Aus-Fallow & 910 & 0.71 & 6 \\
\hline 06 & Fallow-Vegetab-T. Aman & 520 & 0.40 & 5 \\
\hline 07 & Potato-Fallow-T. Aman & 520 & 0.40 & 12 \\
\hline 08 & Vegetab-Vegetab-Vegetab & 450 & 0.35 & 2 \\
\hline 09 & Chilli-Fallow-T. Aman & 380 & 0.30 & 12 \\
\hline 10 & Potato-Aus-T. Aman & 340 & 0.26 & 7 \\
\hline 11 & Garlic-Aus-Fallow & 300 & 0.23 & 1 \\
\hline 12 & Onion-Aus-Fallow & 300 & 0.23 & 1 \\
\hline 13 & Boro-Vegetab(Float/Norm) & 290 & 0.23 & 3 \\
\hline 14 & Potato-Maize-T. Aman & 180 & 0.14 & 4 \\
\hline 15 & Chilli-Fallow-Fallow & 170 & 0.13 & 6 \\
\hline 16 & Chilli-Vegetab-Fallow & 150 & 0.12 & 4 \\
\hline 17 & Potato-Vegetab-T. Aman & 140 & 0.11 & 2 \\
\hline 18 & Potato-Aus-Fallow & 130 & 0.10 & 2 \\
\hline 19 & Potato-Chilli-Fallow & 130 & 0.10 & 2 \\
\hline 20 & Vegetab-Aus-T. Aman & 130 & 0.10 & 4 \\
\hline 21 & Chilli-Aus-Fallow & 120 & 0.09 & 3 \\
\hline 22 & Chilli-Aus-T. Aman & 120 & 0.09 & 2 \\
\hline 23 & Coriander-Fallow-T. Aman & 120 & 0.09 & 8 \\
\hline 24 & Coriander-Fallow-Fallow & 75 & 0.06 & 6 \\
\hline \multirow[t]{2}{*}{$25-32$} & Other eight patterns (in Table 7) & 230 & 0.18 & - \\
\hline & Total & 24205 & 18.80 & \\
\hline
\end{tabular}

Table 7. Rare cropping patterns covering non-significant area in Chittagong Hill Tract, 2014-15.

\begin{tabular}{|c|c|c|c|c|c|}
\hline & Cropping pattern & Area (ha) & $\%$ of NCA & Frequency & Upazila \\
\hline 01 & Maize-Aus-Fallow & 40 & 0.03 & 2 & Rowangchhari+Longadu \\
\hline 02 & Maize-Vegetab-T. Aman & 40 & 0.03 & 2 & Lama+Rajesthali \\
\hline 03 & Onion-Fallow-T. Aman & 40 & 0.03 & 3 & Dighinala+Mahalchhari+Naniarchar \\
\hline 04 & Chilli-Vegetab-T. Aman & 30 & 0.02 & 1 & Ramgarh \\
\hline 05 & Lentil-Fallow-T. Aman & 30 & 0.02 & 3 & Dighinala+Panchhari+Bandarban \\
\hline 06 & Maize-Vegetab-Fallow & 30 & 0.02 & 1 & Bandarban sadar \\
\hline 07 & Onion-Vegtab-Vegetab & 30 & 0.02 & 1 & Thanchi \\
\hline 08 & Garlic-Fallow-Fallow & 25 & 0.02 & 2 & Thanchi+Barkal \\
\hline 09 & Lentil-Vegetab-T. Aman & 20 & 0.02 & 1 & Mahalchhari \\
\hline 10 & Millet(Kaon)+Sesame-F & 20 & 0.02 & 1 & Rangamati sadar \\
\hline 11 & Mungbean-Fallow-T. Aman & 20 & 0.02 & 3 & Bandarban+Dighinala+Khagra \\
\hline 12 & Muskmelon-Fallow-Fallow & 20 & 0.02 & 1 & Thanchi \\
\hline 13 & Mustard-Aus-T. Aman & 20 & 0.02 & 1 & Mahalchhari \\
\hline 14 & Garlic-Fallow-T. Aman & 15 & 0.01 & 2 & Dighinala+Panchhari \\
\hline 15 & Grasspea-Fallow-T. Aman & 15 & 0.01 & 3 & Dighinala+Panchhari+Khagra \\
\hline 16 & Chickpea-Fallow-T. Aman & 10 & 0.01 & 2 & Bandarban+Naniarchar \\
\hline 17 & Fallow-Sesame-T. Aman & 10 & 0.01 & 1 & Matiranga \\
\hline 18 & Mustard-Boro-T. Aman & 10 & 0.01 & 2 & Dighinala+Panchhari \\
\hline 19 & Boro-Fallow-Blackgram & 5 & 0.00 & 1 & Panchhari \\
\hline 20 & Groundnut-Fallow-T. Aman & 5 & 0.00 & 1 & Barkal \\
\hline \multirow[t]{2}{*}{21} & Mustard-Aus-Fallow & 5 & 0.00 & 1 & Rowangchhari \\
\hline & Total & 440 & 0.34 & & \\
\hline
\end{tabular}


coriander, onion and garlic are included in this list. Vegetab-Fallow-Fallow is the most dominating pattern covering 6,310 ha $(4.90 \%$ of NCA) distributed over 17 upazilas. The second one is Vegetab-Fallow-T. Aman with 5,450 ha area, however, it is more widely distributed over 22 upazilas in the region. The total for vegetables and spices crops is 24,205 ha that represents $18.80 \%$ of NCA.

\section{Sporadic and distinct cropping patterns}

There are some cropping patterns which are extremely location-specific, however, with a large area coverage. These are VegetablesVegetables-Vegetables, Garlic-Aus-Fallow and Onion-Aus-Fallow (Table 6). The Vegetables-Vegetables-Vegetables cropping pattern is cultivated in Baghaichhari (300 ha) and in Kaptai (150 ha) in Rangamati district. The second and the third one both are available in Lama upazila of Bandarban district with an area of 300 ha for each.

\section{Most dominant cropping pattern}

Boro-Fallow-T. Aman cropping pattern was the most dominant one in Chittagong Hill Tracts existed in all upazilas except Ruma. The contribution of these upazilas in the existence of the cropping pattern ranged from 0.05 to $10.31 \%$ of the total Boro-Fallow- T. Aman cropping pattern. The largest area coverage under this cropping pattern was in Naikhongchhari (10.31\% of the total) followed by Nannerchar, Dighinala and Khagrachhari sadar upazila. The potentiality of the intensification might be explored consulting other determinants with the stakeholders. The least area coverage was reported in Barkal, Thanchi and Belaichhari (Table 8). In the country-wide compilation of data it was observed that Boro-F-T. Aman was the most dominant cropping pattern in Bangladesh covering 2.31 million ha $(27 \%$ of NCA in the country) with its distribution in 426 upazilas of 63 districts (Nasim et al., 2017).

\section{Second dominant cropping pattern}

Fallow-Fallow-T. Aman cropping pattern ranked the second position in the region distributed to 21 out of 25 upazilas. However, their magnitude of contribution to the region was different, ranging 0.45 (Rowangchhari) to $11.36 \%$ (Dighinala and Naikhongchhari) of the cropping pattern in the region. The major shares from other upazilas were Matiranga, Mohalchhari, Lama, Bandarban, Ramgarh and Manikchhari upazilas (Table 9). In the country-wide data compilation it was observed that the single T. Aman was the $3^{\text {rd }}$ dominant cropping pattern in Bangladesh covering 5.09 lac ha (6\% of NCA in the country) with its distribution in 162 upazilas of 36 districts (Nasim et al., 2017).

\section{Third dominant cropping pattern}

The third cropping pattern in the Chittagong Hill Tracts was zhum cultivation $(9.24 \%$ of the NCA), which was distributed to 20 upazilas with different level of contribution (0.84 to $15.97 \%$ ). The major shares of the cropping pattern belong to Ruma followed Belaichhari, Thanchi and Nannerchar (Table 10). In consideration of individual upazila Ruma upazila has allocated highest area and it is $79.17 \%$ of its NCA for this pattern alone. Lama of Bandarban district and Lakshmichhari upazila of Khragrachhari district had a negligible area coverage for this pattern. Zhum involves clearing of forest following slash and burn method. In February the hilly slopes area cleared. Seeds of sesame and millet are broadcasted mixing with ash before the first shower. Rice, maize and cotton seeds are dibbled later in the month of April after first shower and vegetables such as cucumber seeds are sown in the pit after germination of rice seeds (FAO, 1988).

\section{Fourth dominant cropping pattern}

Vegetables-Fallow-Fallow cropping pattern was recorded as the fourth one in the region covered 17 upazilas ranging 0.16 to $31.70 \%$ contribution in the region (Table 11). The major contributing upazilas for this cropping pattern were Baghaichhari (31.70\%) followed by Mohalchhari (11.09\%) and Kawkhali (9.51\%). Rowangchhari, Bandarban sadar and Khagrachhari sadar upazila had a negligible area for this pattern. 
Table 8. Distribution of most dominant Boro-Fallow-T. Aman cropping pattern in Chittagong Hill Tracts, $2014-15$.

\begin{tabular}{|c|c|c|c|c|}
\hline & Upazila & Area (ha) & $\%$ of upazila NCA & $\%$ of the pattern in region \\
\hline 01 & Naikhongchhari & 2000 & 31.25 & 10.31 \\
\hline 02 & Nannerchar & 1630 & 35.05 & 8.40 \\
\hline 03 & Dighinala & 1500 & 25.64 & 7.73 \\
\hline 04 & Khagrachhari & 1500 & 36.14 & 7.73 \\
\hline 05 & Panchchhari & 1500 & 58.82 & 7.73 \\
\hline 06 & Matiranga & 1300 & 25.24 & 6.70 \\
\hline 07 & Baghaichhari & 1300 & 16.05 & 6.70 \\
\hline 08 & Mohalchhari & 1270 & 21.71 & 6.55 \\
\hline 09 & Lama & 1200 & 15.48 & 6.19 \\
\hline 10 & Bandarban sadar & 1000 & 26.67 & 5.15 \\
\hline 11 & Manikchhari & 900 & 24.32 & 4.64 \\
\hline 12 & Ramgarh & 900 & 21.18 & 4.64 \\
\hline 13 & Alikadam & 750 & 25.42 & 3.87 \\
\hline 14 & Lakshmichhari & 700 & 26.92 & 3.61 \\
\hline 15 & Kawkhali & 600 & 23.53 & 3.09 \\
\hline 16 & Kaptai & 300 & 18.75 & 1.55 \\
\hline 17 & Rajasthali & 300 & 17.65 & 1.55 \\
\hline 18 & Rangamati sadar & 230 & 13.53 & 1.19 \\
\hline 19 & Langadu & 200 & 6.35 & 1.03 \\
\hline 20 & Rowangchhari & 190 & 15.83 & 0.98 \\
\hline 21 & Juraichhari & 60 & 5.00 & 0.31 \\
\hline 22 & Thanchi & 30 & 1.15 & 0.15 \\
\hline 23 & Belaichhari & 30 & 1.15 & 0.15 \\
\hline \multirow[t]{2}{*}{24} & Barkal & 10 & 0.49 & 0.05 \\
\hline & Hill tract & 19400 & 15.07 & 100.00 \\
\hline
\end{tabular}

Table 9. Distribution of second dominant Fallow-Fallow-T. Aman cropping pattern in Chittagong Hill Tracts, $2014-15$.

\begin{tabular}{|c|c|c|c|c|}
\hline & Upazila & Area (ha) & $\%$ of upazila NCA & $\%$ of the pattern in region \\
\hline 01 & Naikhongchhari & 2000 & 31.25 & 11.36 \\
\hline 02 & Dighinala & 2000 & 34.19 & 11.36 \\
\hline 03 & Matiranga & 1700 & 33.01 & 9.65 \\
\hline 04 & Mohalchhari & 1500 & 25.64 & 8.52 \\
\hline 05 & Lama & 1300 & 16.77 & 7.38 \\
\hline 06 & Ramgarh & 1300 & 30.59 & 7.38 \\
\hline 07 & Manikchhari & 1150 & 31.08 & 6.53 \\
\hline 08 & Baghaichhari & 1000 & 12.35 & 5.68 \\
\hline 09 & Bandarban sadar & 950 & 25.33 & 5.39 \\
\hline 10 & Lakshmichari & 800 & 30.77 & 4.54 \\
\hline 11 & Alikadam & 700 & 23.73 & 3.98 \\
\hline 12 & Khagrachhari sadar & 600 & 14.46 & 3.41 \\
\hline 13 & Kawkhali & 600 & 23.53 & 3.41 \\
\hline 14 & Nannerchar & 550 & 11.83 & 3.12 \\
\hline 15 & Langadu & 450 & 14.29 & 2.56 \\
\hline 16 & Kaptai & 320 & 20.00 & 1.82 \\
\hline 17 & Barkal & 250 & 12.20 & 1.42 \\
\hline 18 & Rajasthali & 140 & 8.24 & 0.80 \\
\hline 19 & Belaichhari & 120 & 4.62 & 0.68 \\
\hline 20 & Juraichhari & 100 & 8.33 & 0.57 \\
\hline \multirow[t]{2}{*}{21} & Rowangchhari & 80 & 6.67 & 0.45 \\
\hline & Hill tract & 17610 & 13.68 & 100.00 \\
\hline
\end{tabular}


Table 10. Distribution of third dominant Fallow-Aus+non-rice (zhum) cropping pattern in Chittagong Hill Tracts, $2014-15$.

\begin{tabular}{llrrr}
\hline & Upazila & Area (ha) & \% of upazila NCA & \% of the pattern in region \\
\hline 01 & Ruma & 1900 & 79.17 & 15.97 \\
02 & Belaichhari & 1850 & 71.15 & 15.55 \\
03 & Thanchi & 1300 & 50.00 & 10.92 \\
04 & Nannerchar & 950 & 20.43 & 7.98 \\
05 & Bndarban sadar & 600 & 29.27 & 5.04 \\
06 & Barkal & 600 & 16.00 & 5.04 \\
07 & Mohalchhari & 580 & 9.91 & 4.87 \\
08 & Langadu & 550 & 17.46 & 4.62 \\
09 & Juraichhari & 500 & 41.67 & 4.20 \\
10 & Rajasthali & 500 & 29.41 & 4.20 \\
11 & Rangamati sadar & 470 & 27.65 & 3.95 \\
12 & Kaptai & 380 & 23.75 & 3.19 \\
13 & Khagrachhari & 350 & 8.43 & 2.94 \\
14 & Dighinala & 300 & 11.76 & 2.52 \\
15 & Panchhari & 300 & 5.13 & 2.52 \\
16 & Matiranga & 250 & 4.85 & 2.10 \\
17 & Ramgarh & 150 & 3.53 & 1.26 \\
18 & Kawkhali & 140 & 5.49 & 1.18 \\
19 & Lakshmichhari & 130 & 5.00 & 1.09 \\
20 & Lama & 100 & 1.29 & 0.84 \\
\hline & Hill tract & 11900 & 9.24 & 100.00 \\
\hline
\end{tabular}

Table 11. Distribution of fourth dominant Vegetables-Fallow-Fallow cropping pattern in Chittagong Hill Tracts, $2014-15$.

\begin{tabular}{llrrr}
\hline & Upazila & Area (ha) & \% of upazila NCA & \% of the pattern in region \\
\hline 01 & Baghaichhari & 2000 & 24.69 & 31.70 \\
02 & Mohalchhari & 700 & 11.97 & 11.09 \\
03 & Kawkhali & 600 & 23.53 & 9.51 \\
04 & Matiranga & 580 & 11.26 & 9.19 \\
05 & Thanchi & 540 & 20.77 & 8.56 \\
06 & Ramgarh & 300 & 7.06 & 4.75 \\
07 & Barkal & 300 & 14.63 & 4.75 \\
08 & Rangamati sadar & 250 & 14.71 & 3.96 \\
09 & Ruma & 240 & 10.00 & 3.80 \\
10 & Lama & 200 & 2.58 & 3.17 \\
11 & Belaichhari & 200 & 7.69 & 3.17 \\
12 & Dighinala & 100 & 1.71 & 1.58 \\
13 & Lakshmichhari & 100 & 3.85 & 1.58 \\
14 & Kaptai & 100 & 6.25 & 1.58 \\
15 & Khagra. sadar & 60 & 1.45 & 0.95 \\
16 & Rowangchhari & 30 & 2.50 & 0.48 \\
17 & Bandarban sadar & 10 & 0.27 & 0.16 \\
\hline
\end{tabular}

\section{Fifth dominant cropping pattern}

Vegetables-Fallow-T. Aman cropping pattern ranked fifth in the region which was reported in 22 upazilas ranged 10 to 680 ha (Table 12). This was majorly in Naikhongchhari, Khagrachhari sadar, Lakshmichhari and Baghaichhari upazilas. Thanchi, Matiranga, Rowangchhari and Belaichhari had a very negligible area for this cropping system.

\section{Crop diversity and cropping intensity}

Number of cropping pattern is a gross indicator of crop diversity. The highest number of cropping patterns were recorded in Lama (30) followed by Dighinala (28), Khagrachari sadar (25), Ruma (24), Panchari (23) and Bandarban sadar and Matiranga(20). The number of cropping patterns in Mahalchari, Nannerchar, Langadu, Barkal and Thanchi were 18, 18, 16, 
Table 12. Distribution of fifth dominant Vegetables-Fallow-T. Aman cropping pattern in Chittagong Hill Tracts, $2014-15$.

\begin{tabular}{|c|c|c|c|c|}
\hline & Upazila & Area (ha) & $\%$ of upazila NCA & $\%$ of the pattern in region \\
\hline 01 & Naikhongchhari & 680 & 10.63 & 12.48 \\
\hline 02 & Khagrachhari sadar & 500 & 12.05 & 9.17 \\
\hline 03 & Lakshmichari & 450 & 17.31 & 8.26 \\
\hline 04 & Baghaichhari & 400 & 4.94 & 7.34 \\
\hline 05 & Kawkhali & 350 & 13.73 & 6.42 \\
\hline 06 & Langadu & 350 & 11.11 & 6.42 \\
\hline 07 & Rajasthali & 330 & 19.41 & 6.06 \\
\hline 08 & Manikchhari & 300 & 8.11 & 5.50 \\
\hline 09 & Bandarban sadar & 260 & 6.93 & 4.77 \\
\hline 10 & Barkal & 250 & 12.20 & 4.59 \\
\hline 11 & Nannerchar & 230 & 4.95 & 4.22 \\
\hline 12 & Mohalchhari & 220 & 3.76 & 4.04 \\
\hline 13 & Alikadam & 200 & 6.78 & 3.67 \\
\hline 14 & Lama & 200 & 2.58 & 3.67 \\
\hline 15 & Ramgarh & 200 & 4.71 & 3.67 \\
\hline 16 & Kaptai & 200 & 12.50 & 3.67 \\
\hline 17 & Dighinala & 120 & 2.05 & 2.20 \\
\hline 18 & Rangamati sadar & 100 & 5.88 & 1.83 \\
\hline 19 & Belaichhari & 50 & 1.92 & 0.92 \\
\hline 20 & Rowangchhari & 30 & 2.50 & 0.55 \\
\hline 21 & Matiranga & 20 & 0.39 & 0.37 \\
\hline \multirow[t]{2}{*}{22} & Thanchi & 10 & 0.38 & 0.18 \\
\hline & Hill tract & 5450 & 4.23 & 100.00 \\
\hline
\end{tabular}

15 , and 15, respectively. The lowest number of cropping patterns(8) was reported in Ruma. Higher number of cropping pattern is generally related to higher level of diversity indices for cropping pattern. The upazilas having lower number of cropping patterns were related to hill slope, lack of irrigation water and remoteness. Table 13 presents the calculated diversity indices (CDI) for cropping pattern. The overall crop diversity index for the region was 0.96 . The highest CDI was in Rowangchhari (0.99) followed by Lama, Kaptai, Langadu and Rangamati sadar with same CDI, 0.96 and the lowest CDI was in Thanchi (0.76). Average CI for the Chittagong Hill Tracts was $139 \%$. The lowest CI was recorded in Ruma (100\%) and the highest was in Manikchhari and Panchhari (164\%). Diversified cropping pattern may be resort for the farmer as a coping strategy with flood related risk (Mandal and Bezbaruah, 2013) but scope of diversification is limited due to environmental and climatic condition (FAO, 1988).

\section{CONCLUSION}

The cropping intensity of the Chittagong Hill Tracts was much lower than the national average. About $30 \%$ of the NCA was covered by annual crops mainly with fruits, namely, banana, pineapple, and papaya and the spices, ginger and turmeric.Boro-Fallow-T. Aman, single T. Aman, zhum cultivation, Rabi vegetables and Vegetables-Fallow-T. Aman were the major cropping patterns that covered near about half of the NCA. The large number of existing absolute rice, combination of rice and non-rice based cropping patterns and non-rice-based cropping patterns indicated higher crops and cropping diversity and have the potential of biodiversity conservation, and scope for providing food and nutritional security for the people of the region. The following recommendations were made based on the findings of the study.

- Rice provisioning in the synonym of food security. Therefore, initiative to be taken to increase productivity of exclusive rice based cropping pattern. 
Table 13. Crops and cropping pattern and their diversity indicesin Chittagong Hill Tracts, 2014-15.

\begin{tabular}{|c|c|c|c|c|c|c|}
\hline & Upazila & $\begin{array}{l}\text { Identified cropping } \\
\text { pattern (no.) }\end{array}$ & $\begin{array}{l}\text { No. of } \\
\text { crop }\end{array}$ & $\begin{array}{l}\text { Diversity index for } \\
\text { cropping pattern }\end{array}$ & $\begin{array}{l}\text { Crop diversity } \\
\text { index (CDI) }\end{array}$ & C.I. (\%) \\
\hline 01 & Alikadam & 09 & 07 & 0.93 & 0.95 & 144 \\
\hline 02 & Bandarb. sadar & 22 & 16 & 0.89 & 0.92 & 142 \\
\hline 03 & Lama & 30 & 15 & 0.94 & 0.96 & 154 \\
\hline 04 & Naikhongchhari & 10 & 08 & 0.86 & 0.91 & 161 \\
\hline 05 & Rowangchhari & 24 & 14 & 0.99 & 0.99 & 135 \\
\hline 06 & Ruma & 08 & 07 & 0.92 & 0.92 & 100 \\
\hline 07 & Thanchi & 15 & 15 & 0.85 & 0.76 & 106 \\
\hline 08 & Dighinala & 28 & 20 & 0.89 & 0.92 & 143 \\
\hline 09 & Khagra. sadar & 25 & 16 & 0.89 & 0.92 & 160 \\
\hline 10 & Lakshmichhari & 12 & 09 & 0.89 & 0.92 & 142 \\
\hline 11 & Mohalchhari & 18 & 13 & 0.90 & 0.94 & 150 \\
\hline 12 & Manikchhari & 13 & 09 & 0.85 & 0.91 & 164 \\
\hline 13 & Matiranga & 20 & 13 & 0.88 & 0.92 & 145 \\
\hline 14 & Panchhari & 23 & 17 & 0.82 & 0.87 & 164 \\
\hline 15 & Ramgarh & 12 & 08 & 0.90 & 0.93 & 152 \\
\hline 16 & Baghaichhari & 13 & 10 & 0.86 & 0.92 & 145 \\
\hline 17 & Barkal & 15 & 11 & 0.96 & 0.96 & 112 \\
\hline 18 & Belaichhari & 09 & 07 & 0.81 & 0.82 & 102 \\
\hline 19 & Juraichhari & 12 & 09 & 0.90 & 0.91 & 112 \\
\hline 20 & Kaptai & 09 & 08 & 0.95 & 0.96 & 133 \\
\hline 21 & Kawkhali & 12 & 09 & 0.94 & 0.94 & 125 \\
\hline 22 & Langadu & 16 & 12 & 0.94 & 0.96 & 134 \\
\hline 23 & Nannerchar & 18 & 16 & 0.90 & 0.91 & 132 \\
\hline 24 & Rajasthali & 09 & 07 & 0.93 & 0.95 & 140 \\
\hline \multirow[t]{2}{*}{25} & Rangam. sadar & 14 & 11 & 0.96 & 0.96 & 115 \\
\hline & Chittagong Hill Tract & 72 & 27 & 0.94 & 0.96 & 139 \\
\hline
\end{tabular}

- Short duration high yielding potential Aus rice varieties in suitable for zhum cultivation along with other species of crops for mixed and relay cropping with improved production practices to be extensively adopted for increasing system productivity.

- Initiatives to be taken to expand area under fruit crops in the hilly slope and the demand driven varieties to be adopted considering organic principles.

- The cropping patterns with major area coverage and narrow existence and minor area coverage with minor existence might be sustained for diversified food demand and adaptation to climatic hazard.

- The upazilas having higher cropping pattern index might be studied in depth to extrapolate potential cropping patterns to other upazilas of similar environments.

- Research and development activities can be taken in hand to diversify the single and double cropped cropping pattern with the inclusion of new crops and crop varieties.

- Coordinated programme needs to be taken to conserve the biodiversity and natural resources.

\section{REFERENCES}

Alam, M S. 1994. Optimum cropping patterns of the small farmers under risk: a micro level study in Bangladesh. Ph.D. thesis, Department of Agricultural Economics, Bangladesh Agricultural University, Mymensingh.

Barua, J L, N I Khan, S Barua, S M Mohsin and M R Islam. 2015. Cropping pattern and socio-economic study of 
ethnic people in the hilly areas of Bangladesh. The Agriculturists. 13(1): 119-126.

FAO, 1988. Land Resources Appraisal of Bangladesh for Agricultural Development- Report 2: Agroecological regions of Bangladesh. Food and Agriculture Organization of the United Nations, Rome, Italy, 570p.

Gadge, S S. 2003. Influence of changes in cropping pattern on farmers' economic status. Indian J. Ext. Edu. 39(1\&2): 99-101.

GED (General Economics Division). 2015. $7^{\text {th }}$ Five Year Plan. Bangladesh Planning Commission, Govenment of the People's Republic of Bangladesh, Sher-e-Bangla Nagar, Dhaka 1207. 666p.

Khisa, 1998. Ethnobotanical and cultural background of ethnic communities of forest resource management in Cittagong Hill Tracts. In: Banik, $\mathrm{R}$ L, K Alam, S J Pel and A Rastogi (eds.)., Applied Ethnobotany, Proceedings of Sub regional Training Workshop on Applied Ethnobotany, Bangladesh Forest Research Institute, Chittagong, pp. 56-63.
Kshirsagar, K G, S Pandey and M R Bellon. 1997. Farmers' perception, varietal characteristics and technology adoption: the case of rainfed village in eastern India. Discussion paper 5/97. Social Sciences Division, International Rice Research Institute. Los Baňos, Laguna, Philippines.

Mandal, R and M P Bezbaruah. 2013. Diversification of cropping pattern: its determinants and role in flood affected agriculture of Assam Plains. Indian J. Agric. Econ. 68(2): 169-181.

Nasim, M, S M Shahidullah, A Saha, M A Muttaleb, T L Aditya, M A Ali and M S Kabir. 2017. Distribution of Crops and Cropping Patterns in Bangladesh. Bangladesh Rice J. 21(2): 1-55.

Neena, D. 1998. Interstate variation in cropping pattern in India. Indian J. Regi. Sci. 30(2): 57-69.

Rashid M H, A H Khan and M MAlam. 2005. Cropping systems dynamics in greater Khustia. J. Bangladesh Agril. Univ. 3(2): 213-238.

Appendix 1. List of cropping patterns in Hill tract, 2014-15

\begin{tabular}{|c|c|c|c|c|c|}
\hline & Cropping pattern & Area (ha) & & Cropping pattern & Area (ha) \\
\hline 01 & Boro-Fallow-T. Aman & 19400 & 27 & Onion-Aus-Fallow & 300 \\
\hline 02 & Fallow-Fallow-T. Aman & 17610 & 28 & Boro-Vegetab(Float/Norm) & 290 \\
\hline 03 & Fallow-Aus+Non-rice(zhum) & 11900 & 29 & Potato-Maize-T. Aman & 180 \\
\hline 04 & Vegetab-Fallow-Fallow & 6310 & 30 & Mustard-Fallow-T. Aman & 175 \\
\hline 05 & Vegetab-Fallow-T. Aman & 5450 & 31 & Chilli-Fallow-Fallow & 170 \\
\hline 06 & Boro-Fallow-Fallow & 4950 & 32 & Chilli-Vegetab-Fallow & 150 \\
\hline 07 & Vegetab-Vegetab-Fallow & 4890 & 33 & W.Melon-Aus-T. Aman & 150 \\
\hline 08 & Tobacco-Aus-Fallow & 2250 & 34 & Maize-Aus-T. Aman & 140 \\
\hline 09 & Vegetab-Vegetab-T. Aman & 1850 & 35 & Potato-Vegetab-T. Aman & 140 \\
\hline 10 & Tobacco-Fallow-T. Aman & 1540 & 36 & Potato-Aus-Fallow & 130 \\
\hline 11 & Fallow-Aus-T. Aman & 1320 & 37 & Potato-Chilli-Fallow & 130 \\
\hline 12 & Vegetab-Aus-Fallow & 910 & 38 & Vegetab-Aus-T. Aman & 130 \\
\hline 13 & Boro-Aus-Fallow & 700 & 39 & Chilli-Aus-Fallow & 120 \\
\hline 14 & Fallow-Vegetab-T. Aman & 520 & 40 & Chilli-Aus-T. Aman & 120 \\
\hline 15 & Potato-Fallow-T. Aman & 520 & 41 & Coriander-Fallow-T. Aman & 120 \\
\hline 16 & Boro-Aus-T. Aman & 480 & 42 & Felon-Fallow-Fallow & 120 \\
\hline 17 & Groundnut-Fallow-Fallow & 480 & 43 & W.Melon-Fallow-Fallow & 120 \\
\hline 18 & Tobacco-Fallow-Fallow & 470 & 44 & Maize-Fallow-Fallow & 110 \\
\hline 19 & Vegetab-Vegetab-Vegetab & 450 & 45 & Mustard-Fallow-Fallow & 85 \\
\hline 20 & S.Potato-Fallow-Fallow & 410 & 46 & Maize-Sesame-Fallow & 80 \\
\hline 21 & Maize-Fallow-T. Aman & 400 & 47 & Coriander-Fallow-Fallow & 75 \\
\hline 22 & Chilli-Fallow-T. Aman & 380 & 48 & W.Melon-Fallow-T. Aman & 75 \\
\hline 23 & Felon-Fallow-T. Aman & 370 & 49 & Boro-Maize-Fallow & 60 \\
\hline 24 & Potato-Aus-T. Aman & 340 & 50 & Felon-Aus-Fallow & 50 \\
\hline 25 & S.Potato-Fallow-T. Aman & 320 & 51 & Pea-Fallow-T. Aman & 45 \\
\hline 26 & Garlic-Aus-Fallow & 300 & $52-72$ & Other 21 patterns (Table 7) & 440 \\
\hline
\end{tabular}

